\title{
Penerapan Model Process Oriented Guided Inquiry Learning (POGIL) untuk Meningkatkan Keterampilan Berpikir Kritis Peserta Didik
}

\author{
Adam Malik $^{\text {a) }}$, Vita Oktaviani ${ }^{\text {b) }}$, Wahyuni Handayani ${ }^{\text {c) }}$, \\ Muhammad Minan Chusnid) \\ Program Studi Pendidikan Fisika Jurusan Pendidikan Matematika dan Ilmu Pengetahuan Alam \\ Fakultas Tarbiyah dan Keguruan Universitas Islam Negeri Sunan Gunung Djati Bandung, Indonesia \\ Jl. Raya A.H Nasution No. 105, Bandung 40614 \\ Email: a)adammalik@uinsgd.ac.id, ${ }^{b)}$ oktavianivita2@gmail.com, ${ }^{c}$ wahyuni3666@gmail.com, \\ d)minan.chusni@uinsgd.ac.id
}

\begin{abstract}
This study aims to determine the implementation of learning using Process Oriented Guided Inquiry Learning model (POGIL) and the influence of application of POGIL learning model to the critical thinking skills of students. The method used in this research was pre-experimental design, with the one-group pretest-posttest design. The sample of this research was class $\mathrm{X}$ MIA E which amounted to 36 people selected by using simple random sampling technique. The results showing the average of all teacher activity of meetings was $88.88 \%$ and $87.04 \%$ for the students' activities were in the very good category. In addition, there was an increase in the critical thinking skills of students on the static fluid concept of 0.61 which was included in the medium category. Thus, POGIL learning model can be used as an alternative in improving students' critical thinking skills on the static fluid concept.
\end{abstract}

Keywords: POGIL, critical thinking skills, static fluid

\begin{abstract}
Abstrak
Penelitian ini bertujuan untuk mengetahui keterlaksanaan pembelajaran menggunakan model Process Oriented Guided Inquiry Learning (POGIL) dan pengaruh penerapan model pembelajaran POGIL terhadap keterampilan berpikir kritis peserta didik. Metode dalam penelitian ini menggunakan pre-experimental design, dengan desain one-group pretestposttest. Sampel penelitian ini yaitu kelas X MIA E yang berjumlah 36 orang yang dipilih dengan menggunakan teknik simple random sampling. Hasil penelitian menunjukkan rata-rata seluruh pertemuan aktivitas guru sebesar $88,88 \%$ dan aktivitas peserta didik 87,04\% yang termasuk pada kategori sangat baik. Selain itu, terdapat peningkatan keterampilan berpikir kritis peserta didik pada materi fluida statis sebesar 0,61 yang termasuk pada kategori sedang. Dengan demikian, model pembelajaran POGIL dapat dijadikan sebagai alternatif dalam meningkatkan keterampilan berpikir kritis peserta didik pada materi fluida statis.
\end{abstract}

Kata-kata Kunci: POGIL, keterampilan berpikir kritis, fluida statis 


\section{PENDAHULUAN}

Berpikir kritis bukan merupakan suatu keterampilan yang dapat berkembang dengan sendirinya. Keterampilan ini harus dilatih melalui pemberian rangsangan yang menuntut seseorang untuk berpikir kritis. Sekolah sebagai suatu institusi penyelenggara pendidikan memiliki salah satu tujuan untuk meningkatkan kemampuan siswa berpikir kritis, membuat keputusan rasional, tentang yang diperbuat atau yang diyakini (Nur \& Wikandari, 2000).

Berdasarkan hasil studi pendahuluan di MAN 1 Kota Bandung melalui wawancara dengan salah satu guru fisika dan dengan beberapa peserta didik diketahui bahwa salah satu kesulitan peserta didik dalam pembelajaran fisika adalah melakukan penalaran secara kritis. Ketika guru menjelaskan konsep fisika yang membutuhkan penalaran yang cukup tinggi, hanya sebagian kecil peserta didik yang dapat memahami konsep tersebut. Sebagian besar peserta didik belum mampu melakukan penalaran dan analisis. Peserta didik belum mampu mengajukan pertanyaan dan jawaban mengenai konsep-konsep fisika secara kritis. Metode pembelajaran yang dilakukan oleh guru lebih sering menggunakan metode ceramah. Peserta didik hanya mendengarkan penjelasan guru dan masih menjadikan guru sebagai satu-satunya sumber pembelajaran (teacher centered).

Selanjutnya dilakukan tes keterampilan berpikir kritis pada materi fluida statis untuk menguji keterampilan berpikir kritis peserta didik. Soal dalam bentuk uraian sebanyak dua belas soal, dimana setiap satu soal mewakili satu indikator keterampilan berpikir kritis. Soal diujikan kepada peserta didik kelas XII IPA-3 yang telah memperoleh materi fluida statis, kemudian diperoleh nilai rata-rata sebesar 37,5. Hal ini menunjukkan keterampilan berpikir peserta didik termasuk rendah.

Berdasarkan permasalahan tersebut, diperlukan suatu inovasi pembelajaran yang mampu mengembangkan keterampilan berpikir kritis peserta didik. Keterampilan berpikir kritis dapat dilatih dalam pembelajaran fisika, diantaranya dengan menerapkan model pembelajaran yang berpusat pada peserta didik. Ketika pembelajaran masih berpusat pada guru, peserta didik sulit untuk dapat mengembangkan keterampilan berpikir kritis. Salah satu model pembelajaran yang berpusat pada peserta didik adalah model pembelajaran Process Oriented Guided Inquiry Learning (POGIL).

Model pembelajaran POGIL merupakan pembelajaran yang berorientasi proses yang berpusat pada peserta didik dengan menerapkan learning cycle dalam kegiatan inkuiri terbimbing. Menurut Hanson (2006) langkah-langkah pembelajaran model POGIL meliputi: orientation, yaitu guru memberikan pengetahuan umum tentang materi yang akan dipelajari; exploration, yaitu peserta didik diberi serangkaian tugas yang mengarah pada tujuan pembelajaran, mengumpulkan data dan melaksanakan percobaan; concept formation, yaitu guru mengarahkan dan membimbing peserta didik dalam membangun konsep melalui pertanyaan-pertanyaan kunci serta menghubungkan data yang diperoleh dengan tugasnya; application, yaitu peserta didik mengaplikasikan konsep yang telah ditemukan untuk menyelesaikan soal latihan yang diberikan guru; dan closure, yaitu guru memberikan penguatan dan membimbing peserta didik untuk melakukan refleksi dan evaluasi kinerja kelompoknya.

POGIL merupakan salah satu pembelajaran inkuiri yang berbasis pada konstruksi pemikiran, meningkatkan pemikiran dengan mengajukan jawaban atau pertanyaan (Straumanis dalam Putri \& Sugiarto, 2014). Kelebihan model pembelajaran POGIL diantaranya yaitu dapat membantu peserta didik untuk lebih menemukan sendiri pengetahuannya dan mudah diterapkan pada semua jenjang pendidikan. Selain itu model pembelajaran POGIL juga mampu membantu peserta didik dalam meningkatkan keterampilan proses, bertanya dan mengomunikasikan pengetahuan, serta dapat menjangkau materi pelajaran dalam cakupan yang luas (Zawadzki, 2010).

Berdasarkan hasil penelitian sebelumnya mengenai model pembelajaran POGIL yang dilakukan Sartono dkk (2017) menunjukkan bahwa ada pengaruh keterampilan berpikir analitik peserta didik terhadap masalah sistem imunitas. Kemudian penelitian Mahayana dkk (2016) menunjukkan terdapat pengaruh model POGIL setelah minat siswa dikontrol terhadap pemahaman konsep IPA. Hasil penelitian Ningsih, dkk (2015) menunjukkan penggunaan metode POGIL berpengaruh secara signifikan terhadap keterampilan proses sains peserta didik pada materi suhu dan kalor. Hal ini memperkuat penelitian sebelumnya yang menyatakan bahwa POGIL dapat meningkatkan kemampuan berpikir kritis peserta didik pada pokok bahasan kalor (Ningsih, dkk, 2012). Kemudian penelitian Zamista \& Kaniawati (2015) menunjukkan model POGIL dapat meningkatkan 
kemampuan kognitif dan keterampilan proses sains siswa pada mata pelajaran fisika. Selain itu, Kotwal dan Jain (2015) menyatakan bahwa model pembelajaran POGIL cocok diterapkan pada mata pelajaran kimia karena mampu meningkatkan motivasi belajar peserta didik. Hal ini selaras dengan penelitian yang dilakukan oleh Gale dan Boisselle (2015) yang menyatakan bahwa model pembelajaran POGIL mampu meningkatkan aktivitas belajar mahasiswa pada perkuliahan kimia organik. Selanjutnya, Putri dan Sugiarto (2014) menyatakan bahwa POGIL dapat melatih keterampilan metakognitif pada materi reaksi reduksi-oksidasi. Selain itu, penelitian yang dilakukan oleh Widyaningsih, dkk (2012) menunjukkan Model Free Inquiry (MFI) dan POGIL mampu meningkatkan aktivitas belajar dan kreativitas peserta didik pada konsep elektrolisis.

\section{METODE PENELITIAN}

Metode yang digunakan dalam penelitian ini adalah metode pre-experiment yang dilaksanakan pada satu kelas penelitian (kelas eksperimen) tanpa adanya kelas pembanding (kelas kontrol). Desain yang digunakan dalam penelitian ini adalah one-group pretest-posttest design. Representasi desain one-group pretest-posttest seperti dijelaskan dalam Fraenkel and Wallen (2007).

Populasi dari penelitian ini adalah seluruh peserta didik kelas X MIA di MAN 1 Kota Bandung yang terdiri atas enam kelas dengan peserta didik sebanyak 216 orang. Sampel penelitian ditentukan dengan teknik simple random sampling. Pengambilan sampel ini dilakukan dengan cara mengundi satu kelas dari enam kelas yang ada dan diperoleh kelas X MIA E sebanyak 36 peserta didik.

Instrumen penelitian yang digunakan terdiri dari: pertama, lembar observasi digunakan untuk mendapatkan data keterlaksanaan model POGIL pada materi fluida statis. Observer memberi tanda $(\mathrm{x})$ pada kolom "Ya" dan tanda checklist $(\sqrt{ })$ pada kolom "Tidak" untuk masing-masing tahapan. Untuk kolom "Ya" terdapat lima kategori pilihan nilai, yaitu jika yang dipilih poin (5) maka nilainya $100 \%$, jika poin (4) maka $80 \%$, jika poin (3) maka nilainya $60 \%$, jika poin (2) maka nilainya $40 \%$ dan jika poin (1) maka nilainya $20 \%$ dan jika memilih kolom "tidak" maka bernilai 0 . Hasil perhitungan seluruh keterlaksanaan aktivitas guru dan peserta didik diolah dan dihitung dalam bentuk persentase kemudian diinterpretasikan hasilnya. Selain itu, observer juga memberikan komentar pada lembar observasi mengenai keterlaksanaan pada setiap aktivitas yang dilakukan guru dan peserta didik selama pembelajaran. Aktivitas guru dan peserta didik pada setiap pertemuan (pertama sampai ketiga) sebanyak 54 kegiatan. Instrumen kedua, tes Keterampilan Berpikir Kritis (KBK) dilaksanakan untuk mengetahui seberapa signifikan peningkatan KBK peserta didik pada materi fluida statis. Tes ini diujikan diawal dan diakhir penelitian dalam bentuk uraian dengan jumlah soal sebanyak 12. Indikator keterampilan berpikir kritis yang diukur mengacu pada framework Ennis (1985) meliputi: memberikan penjelasan sederhana (elementary clarification), membangun keterampilan dasar (basic support), menyimpulkan (inference), membuat penjelasan lebih lanjut (advanced clarification), dan strategi dan taktik (strategies and tactics). Pedoman penskoran untuk tes KBK menggunakan rublik penilaian dengan rentang skor yang diberikan untuk setiap soal dari 0 sampai 4. Untuk menguji kesahihan tes dilakukan uji coba instrumen. Data hasil uji coba instrumen dianalisis dengan menggunakan software program Anates 4.0.9. Peningkatan N-gain KBK menggunakan rumus Hake (Cheng et al., 2004). Uji hipotesis dilakukan dengan menggunakan teknik uji statistik yang sesuai dengan distribusi data yang diperoleh. Pengolahan dan perhitungan data dengan menggunakan program Microsoft Excel dimana sebelum dilakukan uji hipotesis, terlebih dahulu dilakukan uji normalitas.

\section{HASIL DAN PEMBAHASAN}

\section{Keterlaksanaan Model Pembelajaran Process Oriented Guided Inquiry Learning (POGIL)}

Hasil analisis menunjukkan bahwa aktivitas guru dan peserta didik pada pembelajaran menggunakan model POGIL mengalami peningkatan pada setiap pertemuan. Interpretasi keterlaksanaan aktivitas guru dan peserta didik secara keseluruhan dapat dilihat pada TABEL 1. 
TABEL 1. Interpretasi Keterlaksanaan Aktivitas Guru dan Peserta Didik

\begin{tabular}{ccccc}
\hline Pertemuan & \multicolumn{5}{l}{ Keterlaksanaan Model POGIL } \\
\cline { 2 - 5 } & $\begin{array}{c}\text { Guru } \\
(\boldsymbol{\%})\end{array}$ & Interpretasi & Peserta didik (\%) & Interpretasi \\
& 79.24 & Baik & 77.49 & Baik \\
2 & 92.89 & Sangat baik & 90.03 & Sangat baik \\
3 & 94.51 & Sangat baik & 93.59 & Sangat baik \\
Rata-rata & 88.88 & Sangat baik & 87.04 & Sangat baik \\
\hline
\end{tabular}

Keterlaksanaan aktivitas guru dan peserta didik pada setiap pertemuan menggunakan model POGIL mengalami peningkatan. Aktivitas guru dan pesert didik pada pertemuan kedua meningkat cukup signifikan. Guru pada pertemuan ke-2 sudah mampu mengkondisikan peserta didik dan peserta didik sudah memahami langkah-langkah model pembelajaran POGIL. Guru tidak mengalami kesulitan dalam memberikan arahan kepada peserta didik dan lebih mudah mengkodisikan peserta didik dalam merancang dan melakukan percobaan. Secara keseluruhan aktivitas peserta didik dan guru dalam pertemuan ke-2 terlaksana dengan sangat baik. Guru pada pertemuan ke-3 sudah mampu mengkondisikan peserta didik dan peserta didik sudah terbiasa dengan langkah-langkah model pembelajaran POGIL, sehingga pembelajaran yang berorientasi peserta didik dapat berlangsung dengan baik. Peserta didik lebih aktif dan mudah dalam merancang dan melakukan kegiatan percobaan pada pertemuan ke-3.

Salah satu kelebihan model pembelajaran POGIL yaitu dapat membantu peserta didik untuk lebih menemukan sendiri pengetahuannya dan terbiasa bekerjasama dalam tim (Zawadzki, 2010). Proses pembelajaran yang dilakukan secara kerjasama tim ini membuat peserta didik lebih mengasah keterampilan beripikr kritis peserta didik, karena dalam kelompok peserta didik dapat saling bertukar ide atau pikiran untuk memecahkan suatu permasalahan.

Interpretasi keterlaksanaan aktivitas guru dan aktivitas peserta didik pada setiap tahap model pembelajaran POGIL ditunjukkan pada TABEL 2. berikut.

TABEL 2. Keterlaksanaan Setiap Tahap Model Pembelajaran POGIL pada Setiap Pertemuan

\begin{tabular}{|c|c|c|c|c|c|c|c|c|c|c|}
\hline \multirow{2}{*}{$\begin{array}{c}\text { Langkah } \\
\text { Model } \\
\text { POGIL }\end{array}$} & \multicolumn{2}{|c|}{$\begin{array}{c}\text { Pertemuan } \\
\text { ke-1 } \\
\end{array}$} & \multicolumn{2}{|c|}{$\begin{array}{c}\text { Pertemuan } \\
\text { ke-2 }\end{array}$} & \multicolumn{2}{|c|}{$\begin{array}{c}\text { Pertemuan } \\
\text { ke-3 }\end{array}$} & \multicolumn{2}{|c|}{ Rata-rata } & \multicolumn{2}{|c|}{ Interpretasi } \\
\hline & $\begin{array}{c}\text { Guru } \\
(\%)\end{array}$ & $\begin{array}{c}\text { Peserta } \\
\text { didik } \\
(\%)\end{array}$ & $\begin{array}{c}\text { Guru } \\
(\%)\end{array}$ & $\begin{array}{c}\text { Peserta } \\
\text { didik } \\
(\%)\end{array}$ & $\begin{array}{c}\text { Guru } \\
(\%)\end{array}$ & $\begin{array}{c}\text { Peserta } \\
\text { didik } \\
(\%)\end{array}$ & $\begin{array}{c}\text { Guru } \\
(\%)\end{array}$ & $\begin{array}{c}\text { Peserta } \\
\text { didik } \\
(\%)\end{array}$ & Guru & $\begin{array}{c}\text { Peserta } \\
\text { didik }\end{array}$ \\
\hline Pendahuluan & 75,56 & 75,56 & 94,44 & 92,22 & 96,67 & 94,44 & 88,89 & 87,41 & Sangat baik & Sangat baik \\
\hline $\begin{array}{l}\text { Tahap } \\
\text { oriented }\end{array}$ & 80,00 & 74,67 & 96,00 & 96,00 & 97,33 & 94,67 & 91,11 & 88,44 & Sangat baik & Sangat baik \\
\hline $\begin{array}{l}\text { Tahap } \\
\text { exploration }\end{array}$ & 93,33 & 83,33 & 96,67 & 96,67 & $\begin{array}{c}100,0 \\
0\end{array}$ & 96,67 & 96,67 & 92,22 & Sangat baik & Sangat baik \\
\hline $\begin{array}{l}\text { Tahap } \\
\text { concept } \\
\text { formation }\end{array}$ & 78,67 & 78,67 & 90,67 & 81,33 & 96,00 & 93,33 & 88,44 & 84,44 & Sangat baik & Baik \\
\hline $\begin{array}{l}\text { Tahap } \\
\text { application }\end{array}$ & 66,67 & 73,33 & 86,67 & 80,00 & 86,67 & 86,67 & 80,00 & 80,00 & Baik & Baik \\
\hline $\begin{array}{l}\text { Tahap } \\
\text { closure }\end{array}$ & 77,78 & 75,56 & 91,11 & 93,33 & 88,89 & 93,33 & 85,93 & 87,41 & Baik & Sangat baik \\
\hline Penutup & 82,67 & 81,33 & 94,67 & 90,67 & 96,00 & 96,00 & 91,11 & 89,33 & Sangat baik & Sangat baik \\
\hline Rata-rata & 79,24 & 77,49 & 92,89 & 90,03 & 94,51 & 93,59 & 88,88 & 87,04 & & \\
\hline Interpretasi & Baik & Baik & $\begin{array}{c}\text { Sangat } \\
\text { baik }\end{array}$ & $\begin{array}{l}\text { Sangat } \\
\text { baik }\end{array}$ & $\begin{array}{c}\text { Sangat } \\
\text { baik }\end{array}$ & $\begin{array}{c}\text { Sangat } \\
\text { baik }\end{array}$ & $\begin{array}{l}\text { Sangat } \\
\text { baik }\end{array}$ & $\begin{array}{c}\text { Sangat } \\
\text { baik }\end{array}$ & & \\
\hline
\end{tabular}

Rata-rata keterlaksanaan aktivitas guru dan peserta didik berkategori sangat baik. Aktivitas guru pada tahap exploration mendapatkan rata-rata tertinggi pada setiap pertemuan dengan persentase 96,67\% berkategori sangat baik. Sejalan dengan aktivitas guru, aktivitas peserta didik yang 
memperoleh rata-rata tertinggi pada tahap exploration dengan persentase 92,22\% dengan kategori sangat baik. Tahap exploration merupakan tahap dimana peserta didik dibimbing guru untuk merencanakan dan melakukan percobaan untuk menemukan konsep. Peserta didik antusias dalam kegiatan percobaan. Semua yang dipertanyakan pada tahap sebelumnya dapat diselidiki jawabannya pada tahap ini. Selain itu peserta didik yang sebelumnya cenderung pasif dapat lebih mengembangkan keterampilan psikomotoriknya melalui kegiatan percobaan pada tahap ini. Menurut Ningsih (2012) melalui eksperimen terbimbing secara signifikan dapat memperbaiki kemampuan peserta didik untuk memahami argumen dan masalah yang dipecah di dalam kelas. Peserta didik memiliki pengalaman belajar sehingga peserta didik lebih mudah memahami konsep fisika yang dipelajari. Hal ini sejalan dengan Bruner dalam Widyaningsih dkk (2012), bahwa dalam pembelajaran peserta didik akan menjadi lebih memahami konsep apabila selama proses pembelajaran tersebut peserta didik mengalami secara langsung dan berpartisipasi aktif sehingga memperoleh pengalaman melalui eksperimen ataupun dengan model lain yang bisa memberikan suatu kebebasan bagi peserta didik untuk menemukan sendiri konsep dan prinsip suatu materi.

Rata-rata persentase terendah aktivitas guru dan peserta didik pada setiap pertemuan terjadi pada tahap application dengan persentase 80,00\% termasuk kategori baik. Kesulitan di tahap application ini karena peserta didik harus dapat menerapkan konsep pada situasi atau permasalahan yang lebih kompleks yang membutuhkan penalaran yang lebih tinggi. Guru pada tahap ini tidak banyak berperan, hanya memberi soal kepada peserta didik. Kerjasama tim dalam kelompok berperan penting pada tahap ini, peserta didik diharapkan mau menggali lebih lanjut tentang konsep yang telah ditemukan. Peserta didik pada umumnya kesulitan dan hanya beberapa orang saja yang dapat mencari tahu konsep lebih lanjut. Menurut Tawil dan Liliasari (2013) penggunaan metode kooperatif dan pemecahan masalah berkolaborasi dapat mengembangkan keterampilan berpikir kritis, peserta didik terlibat aktif secara individual dan juga dalam kerja kelompok.

Kendala atau kekurangan yang dialami pada saat pembelajaran dengan menggunakan model pembelajaran POGIL ini adalah masalah waktu yang belum bisa dialokasikan dengan baik, ketertiban peserta didik saat pembelajaran, sikap pasif peserta didik, dan kemauan peserta didik untuk mencari referensi tambahan. Hal ini sesuai dengan pendapat Zawadzki (2010) yang menyatakan kelemahan model POGIL diantaranya sangat sulit dilaksanakan bila sarana seperti buku paket tidak disediakan di sekolah dan jika dilaksanakan di kelas yang sulit diarahkan untuk pembelajaran maka pembelajaran tidak akan efektif . Guru dalam menggunakan model pembelajaran POGIL harus dapat menciptakan situasi pembelajaran yang membuat peserta didik merasa nyaman dan aktif terlibat di dalamnya. Peserta didik akan belajar dengan segenap kemampuannya apabila menyukai apa yang dipelajari dan akan aktif terlibat di dalamnya. Sebelum memulai pembelajaran lebih baik diberikan dulu penjelasan kepada peserta didik mengenai langkah-langkah pada model pembelajaran POGIL, sehingga proses pembelajaran akan berjalan sesuai yang diharapkan.

\section{Peningkatan Keterampilan Berpikir Kritis Peserta didik}

Peningkatan keterampilan berpikir kritis peserta didik yang diperoleh dari rata-rata nilai pretest, posttest, dan $\mathrm{N}$-gain pada materi fluida statis secara keseluruhan tertera dalam TABEL 3 berikut.

TABEL 3. Skor Pretest, Posttest, dan Normal Gain

\begin{tabular}{ccccc}
\hline & \multicolumn{2}{c}{ Skor } & $N$-gain & Kategori \\
\hline & Pretest & Posttest & & \\
Rata-rata & 36,69 & 75,64 & 0,61 & Sedang \\
\hline
\end{tabular}

Dari hasil analisis data kategori $N$-gain menunjukan bahwa keterampilan berpikir kritis peserta didik pada materi fluida statis menjadi lebih baik setelah dilakukan pembelajaran dengan menggunakan model pembelajaran POGIL. Hal ini sejalan dengan penelitian Ningsih, dkk (2012) yang menyatakan bahwa model pembelajaran POGIL dapat meningkatkan keterampilan berpikir kritis peserta didik. Adapun rincian banyaknya peserta didik pada setiap kategori peningkatan keterampilan berpikir kritis disajikan pada TABEL 4 berikut. 
TABEL 4. Persentase Banyaknya Peserta Didik Setiap Kategori Peningkatan

\begin{tabular}{ccc}
\hline $\begin{array}{c}\text { Banyaknya Peserta } \\
\text { Didik }\end{array}$ & Persentase (\%) & Kategori \\
\hline 0 & 0 & Rendah \\
28 & 78 & Sedang \\
8 & 22 & Tinggi \\
\hline
\end{tabular}

Rata-rata skor pretest, posttest dan $N$-gain untuk setiap sub konsep indikator keterampilan berpikir kritis peserta didik dapat dilihat pada TABEL 5 berikut.

TABEL 5. Skor Pretest, Posttest dan N-Gain untuk Setiap Sub Konsep

\section{Sub Konsep}

Tekanan hidrostatis dan hukum Pascal Hukum Archimedes

Tegangan permukaan dan gejala kapilaritas

\begin{tabular}{cccc}
\multicolumn{2}{l}{ Rata-rata } \\
\hline Pretest & Posttest & N-Gain & $\begin{array}{c}\text { Inter- } \\
\text { pretasi }\end{array}$ \\
38,61 & 76,25 & 0,61 & Sedang \\
21,53 & 77,78 & 0,65 & Sedang \\
36,11 & 73,47 & 0,58 & Sedang \\
\hline
\end{tabular}

Nilai rata-rata $\mathrm{N}$-gain sub konsep tertinggi terdapat pada sub konsep hukum Archimedes dengan nilai sebesar 0,65 termasuk kategori sedang. Peserta didik pada sub konsep ini mampu mengembangkan keterampilan berpikirnya untuk menghubungkan berbagai permasalahan dengan konsep dan menggunakan model sebab akibat dari sebuah permasalahan yang sudah diberikan. Nilai rata-rata $\mathrm{N}$-gain sub konsep terendah yaitu 0,58 termasuk kategori sedang terdapat pada sub konsep tegangan permukaan dan gejala kapilaritas. Kebanyakan peserta didik kurang tepat dalam menjawab soal mengidentifikasi asumsi yang berkaitan dengan gaya kohesi dan adhesi. Hal ini berkaitan dengan kurangnya kemampuan berpikir peserta didik dalam menghubungkan konsep yang satu dengan yang lainnya. Ada baiknya sebelum pembelajaran dimulai guru memaparkan kembali sebagian kecil materi yang menjadi materi prasyarat walaupun materi tersebut pernah dipelajari di SMP, tetapi sebagian besar peserta didik biasanya lupa atau justru belum memahami materi dasar tersebut. Hal ini selaras dengan pendapat Moog dan Spencer (2008) yang menyatakan tahap orientation pada model POGIL diawali dengan pemberian informasi atau data dan dibimbing dengan pertanyaan untuk dapat menyusun suatu kesimpulan.

Rata-rata skor pretest, posttest dan $\mathrm{N}$-gain untuk setiap aspek keterampilan berpikir kritis peserta didik dapat dilihat pada TABEL 6 berikut.

TABEL 6. Skor Pretest, Posttest dan N-Gain untuk Setiap Aspek Keterampilan Berpikir Kritis (KBK)

\begin{tabular}{|c|c|c|c|c|}
\hline \multirow{2}{*}{$\begin{array}{l}\text { Aspek Keterampilan Berpikir } \\
\text { Kritis }\end{array}$} & \multicolumn{4}{|c|}{ Rata-rata } \\
\hline & Pretest & Posttest & $N$-Gain & Interpretasi \\
\hline Memberikan penjelasan sederhana & 39,67 & 76,67 & 0,61 & Sedang \\
\hline Membangun keterampilan dasar & 37,00 & 77,00 & 0,63 & Sedang \\
\hline Menyimpulkan & 35,00 & 79,00 & 0,68 & Sedang \\
\hline $\begin{array}{l}\text { Memberikan penjelasan lebih } \\
\text { lanjut }\end{array}$ & 48,50 & 73,50 & 0,49 & Sedang \\
\hline Strategi dan taktik & 23,00 & 69,50 & 0,60 & Sedang \\
\hline
\end{tabular}

Berdasarkan lima aspek keterampilan berpikir kritis, aspek menyimpulkan memiliki nilai $\mathrm{N}$-gain tertinggi yaitu 0,68 termasuk pada kategori sedang. Hal ini dikarenakan pada setiap pertemuan peserta didik dilatih untuk membuat kesimpulan berdasarkan percobaan dan konsep yang telah 
ditemukan. Hal ini selaras dengan hasil penelitian Malik (2010) yang menunjukkan peningkatan Ngain tertinggi terjadi pada indikator menyimpulkan. Hal ini dikarenakan peserta didik pada setiap pertemuan telah terlatih untuk membuat kesimpulan dari data hasil suatu percobaan. Sebagaimana yang dikemukakan Putri dan Sugiarto (2014) yang menyatakan bahwa dengan model pembelajaran POGIL peserta didik terbiasa menarik kesimpulan untuk memecahkan masalah berdasarkan konsep yang telah dibangun dari hasil kegiatan percobaan kelompok. Selain itu, dalam aktivitas pembelajaran POGIL selalu mengikutsertakan peserta didik untuk membangun kembali informasi dan pengetahuan serta mengembangkan pemahamannya dalam memecahkan suatu permasalahan (Hanson, 2006). Aspek memberikan penjelasan lebih lanjut mempunyai nilai $\mathrm{N}$-gain terendah yaitu 0,49 termasuk pada kategori sedang. Hal ini dikarenakan peserta didik kurang maksimal dalam mencari referensi tambahan dan kurang optimalnya peserta didik dalam berpendapat ketika mengerjakan soal secara kelompok. Menurut Ningsih (2012) peserta didik dapat lebih optimal dalam membangun pengetahuannya dengan bertukar pendapat dalam kelompok dalam pengerjaan soal-soal yang kompleks.

Nilai rata-rata skor pretest, posstest dan $N$-gain untuk setiap sub indikator keterampilan berpikir kritis peserta didik dapat dilihat pada TABEL 7 berikut.

TABEL 7. Skor Pretest, Posttest dan N-gain untuk Setiap Sub Indikator Keterampilan Berpikir Kritis

\begin{tabular}{|c|c|c|c|c|}
\hline \multirow[b]{2}{*}{$\begin{array}{l}\text { Sub Indikator Keterampilan Berpikir } \\
\text { Kritis }\end{array}$} & \multicolumn{4}{|c|}{ Rata-rata } \\
\hline & Pretest & Posttest & $\begin{array}{c}N- \\
\text { Gain }\end{array}$ & $\underset{\mathbf{i}}{\text { Interpretas }}$ \\
\hline Memfokuskan pertanyaan & 42,00 & 83,00 & 0,71 & Tinggi \\
\hline Menganalisis argumen & 42,00 & 78,00 & 0,62 & Sedang \\
\hline $\begin{array}{l}\text { Bertanya dan menjawab pertanyaan tentang suatu } \\
\text { penjelasan dan tantangan }\end{array}$ & 35,00 & 69,00 & 0,52 & Sedang \\
\hline Mempertim-bangkan kredibilitas suatu sumber & 34,00 & 76,00 & 0,64 & Sedang \\
\hline $\begin{array}{l}\text { Mengobservasi dan mempertimbangkan hasil } \\
\text { observasi }\end{array}$ & 40,00 & 78,00 & 0,63 & Sedang \\
\hline Mendeduksi dan mempertimbangkan hasil deduksi & 38,00 & 81,00 & 0,69 & Sedang \\
\hline Menginduksi dan mempertimbangkan hasil induksi & 41,00 & 74,00 & 0,56 & Sedang \\
\hline Membuat dan mempertimbangkan nilai keputusan & 26,00 & 82,00 & 0,76 & Tinggi \\
\hline $\begin{array}{l}\text { Mendefinisi-kan istilah dan mempertimbangkan } \\
\text { definisi }\end{array}$ & 50,00 & 82,00 & 0,64 & Sedang \\
\hline Mengidentifikasi asumsi & 47,00 & 65,00 & 0,34 & Sedang \\
\hline Menentukan tindakan & 13,00 & 70,00 & 0,66 & Sedang \\
\hline Berinteraksi dengan orang lain & 33,00 & 69,00 & 0,54 & Sedang \\
\hline
\end{tabular}

Berdasarkan dua belas sub indikator keterampilan berpikir kritis, sub indikator membuat dan mempertimbangkan hasil keputusan memperoleh nilai $N$-gain tertinggi yaitu sebesar 0,76 termasuk interpretasi tinggi. Hal ini dikarenakan pada setiap pertemuan, peserta didik selalu dilibatkan dalam aktivitas untuk berhipotesis dan membuktikannya dengan percobaan untuk memeriksa setiap hasil keputusan berdasarkan bukti pendukungnya. Hal ini sejalan dengan pernyataan Sulatriningsih dan Suranata (2014) yang menyatakan bahwa masalah yang dijadikan fokus pembelajaran dalam model POGIL dapat diselesaikan peserta didik melaui tahap aktivitas inkuiri terbimbing. Peserta didik melalui tahap inkuiri terbimbing diharapkan dapat mengemukakan gagasan awal (hipotesis) dan menguji hipotesis melalui kegiatan percobaan yang dibimbing.

Sub indikator keterampilan berpikir kritis mengidentifikasi asumsi memiliki nilai $\mathrm{N}$-gain terendah yaitu sebesar 0,34 termasuk interpretasi sedang. Hal ini dikarenakan ketika membuat penjelasan lebih lanjut yang salah satunya dapat dikembangkan pada tahap application dalam model POGIL berlangsung kurang optimal. Ketika menyelesaikan soal secara berkelompok belum semua peserta didik dalam kelompok mencari tahu lebih lanjut tentang konsep yang dipelajari, sehingga kesulitan untuk mengidentifikasi asumsi. Menurut Putra dan Sudarti (2015) indikator keterampilan berpikir 
kritis mengidentifikasi asumsi dikembangkan dengan baik jika peserta didik terlibat dalam pembelajaran aktif untuk memecahkan suatu permasalahan.

Uji normalitas dilakukan untuk mengetahui normal atau tidaknya suatu data. Rekapitulasi hasil uji coba normalitas dapat dilihat pada TABEL 8 berikut.

TABEL 8. Hasil Uji Normalitas Pretest dan Posttest

\begin{tabular}{lcc}
\hline \multicolumn{1}{c}{ Kriteria } & Data pretest & Data posttest \\
\hline Jumlah peserta didik & 36 & 36 \\
$\chi_{\text {hitung }}^{2}$ & 6,86 & 89,63 \\
$\chi_{\text {tabel }}^{2}=\chi_{(1-0,05)(d k)}^{2}$ & 3,84 & 101,88 \\
Hasil & $\chi^{2}{ }_{\text {hitung }}>\chi_{\text {tabel }}^{2}$ & $\chi^{2}{ }_{\text {hitung }}<\chi_{\text {tabel }}^{2}$ \\
Kriteria & $\begin{array}{l}\text { Data berdistribusi tidak } \\
\text { normal }\end{array}$ & $\begin{array}{c}\text { Data berdistribusi } \\
\text { normal }\end{array}$ \\
\hline
\end{tabular}

Berdasarkan TABEL 7 di atas, diketahui nilai chi kuadrat untuk data pretest $\chi^{2}{ }_{\text {hitung }}(6,86)$ $>\chi^{2}$ tabel $(3,84)$, yang menunjukkan bahwa data pretest keterampilan berpikir kritis peserta didik pada materi fluida statis berdistribusi tidak normal. Data posttest diketahui $\chi^{2}{ }_{\text {hitung }}(89,63)<\chi^{2}{ }_{\text {tabel }}$ $(101,88)$, yang menunjukkan bahwa data posttest keterampilan berpikir kritis peserta didik pada materi fluida statis berdistribusi normal. Karena salah satu dari kedua data tidak normal maka dilakukan uji Wilcoxon match pair test.

Rekapitulasi hasil analisis uji hipotesis menggunakan Wilcoxon match pair test dapat ditunjukkan pada TABEL 9 berikut.

TABEL 9. Hasil Uji Hipotesis Menggunakan Uji Wilcoxon

\begin{tabular}{cc}
\hline Kriteria & Nilai \\
\hline Jumlah peserta didik $(N)$ & 36 \\
$\mathrm{~T}$ & 0 \\
$\mu_{T}$ & 333 \\
$\sigma_{T}$ & 63,65 \\
$Z_{\text {hitung }}$ & 9,09 \\
$Z_{\text {Tabel }(\alpha=0.05)}$ & 1,65 \\
Hasil & $Z_{\text {hitung }}>Z_{\text {Tabel }}$ \\
Kriteria & Terdapat perbedaan yang signifikan \\
\hline
\end{tabular}

Berdasarkan hasil perhitungan uji hipotesis menggunakan uji Wilcoxon match pair test diperoleh nilai $Z_{\text {hitung }}=9,09$ dengan taraf signifikasi 0,05 besarnya nilai $Z_{\text {Tabel }}=1,65$. Berdasarkan data tersebut menunjukkan bahwa nilai $Z_{\text {hitung }}$ lebih besar dari nilai $Z_{\text {Tabel }}(9,09>1,65)$, sehingga hipotesis $\left(H_{0}\right)$ ditolak dan hipotesis $\left(\mathrm{H}_{\mathrm{a}}\right)$ diterima. Hal ini dapat disimpulkan terdapat pengaruh yang signifikan mengenai penerapan model pembelajaran POGIL dalam meningkatkan keterampilan berpikir kritis peserta didik pada materi fluida statis.

Model pembelajaran POGIL membantu peserta didik lebih menemukan sendiri pengetahuannya, meningkatkan keterampilan berpikir melalui bertanya dan mengkomunikasikan pengetahuan. Penggunaan model pembelajaran POGIL berhubungan dengan salah satu teori belajar yaitu teori konstruktivisme. Menurut teori konstruktivisme, belajar adalah kegiatan yang aktif dimana peserta didik membangun sendiri pengetahuannya dan mencari makna dari sesuatu yang mereka pelajari. Berdasarkan paham konstruktivisme, belajar adalah proses pemecahan masalah (Karli \& Margeretha, 2014). Peserta didik dalam proses pemecahan suatu masalah dituntut untuk dapat mengidentifikasi dan membuat hipotesis yang kemudian hipotesis tersebut diuji melalui hasil pengamatan. Inilah yang menyebabkan keterampilan berpikir kritis peserta didik selama pembelajaran menggunakan model pembelajaran POGIL mengalami peningkatan. Berdasarkan hasil analisis dan pembahasan di atas, 
dapat disimpulkan bahwa penerapan model pembelajaran POGIL dapat meningkatkan keterampilan berpikir kritis peserta didik khususnya pada meteri fluida statis.

\section{PENUTUP}

Aktivitas peserta didik dan guru selama kegiatan pembelajaran fisika dengan menggunakan model pembelajaran POGIL di kelas X MIA MAN 1 Kota Bandung mengalami peningkatan dengan ratarata seluruh aktivitas guru sebesar $88,88 \%$ dan rata-tata aktivitas peserta didik sebesar 87,04\%, keduanya termasuk pada kategori sangat baik. Tahap application merupakan tahapan dengan ratarata keterlaksanaan terendah karena pada tahap ini merupakan tahap yang memerlukan penalaran yang lebih tinggi. Oleh karena itu, guru sebaiknya dapat membimbing peserta didik untuk mau mencari konsep lebih lanjut melalui referensi tambahan dan saling bertukar pikiran dengan anggota kelompoknya dalam memecahkan soal permasalahan pada tahap ini.

Keterampilan berpikir kritis peserta didik mengalami peningkatan setelah diterapkan model pembelajaran POGIL pada materi fluida statis yang ditunjukkan dengan rata-rata indeks normal gain sebesar 0,61 termasuk pada kategori sedang. Sub indikator keterampilan berpikir kritis mengidentifikasi asumsi memperoleh normal gain terendah. Oleh karena itu, guru hendaknya mengarahkan peserta didik agar mampu membuat penjelasan lebih lanjut misalnya dengan memberikan kesempatan pada peserta didik untuk mencari referensi tambahan berbagai sumber sehingga peserta didik tidak kesulitan untuk melakukan penalaran secara implisit dan mengidentifikasi asumsi.

\section{UCAPAN TERIMA KASIH}

Terima kasih kepada Kepala Sekolah dan Guru Fisika MAN 1 Kota Bandung yang telah memberikan izin untuk dijadikan sebagai tempat penelitian dan membantu selama penelitian.

\section{REFERENSI}

Cheng, KK, et al 2004, Using online homework system enhances students learning of physics concepts in an introductory physics course, American Journal of Physics, vol. 72, no. 11, pp. $1447-1453$.

Ennis, RH 1985, An elaboration of a cardinal goal of science instruction, Educational Philosophy and Theory, vol. 23, no. 1, pp. 31-34.

Fraenkel, JR \& Wallen, NE 2007, How to design and evaluate research in education, 6th edn, McGraw-Hill Book Co, New York.

Gale, SD \& Boiselle LN 2015, The effect of POGIL on academic performance confidence, Science Education International, Vol. 26, Issue 1, pp. 56-61.

Hanson 2006, Beyond constructivism: Models and modeling perspective on physics problem solving, learning, and teaching, LEA, London.

Karli, H. \& Margaretha, SY 2004, Implementasi Kurikulum Berbasis Kompetensi, Bina Media Informasi, Bandung.

Kotwal, Marazban \& Jain, Abhilasha 2015, Implementing process-oriented guided inquiry learning in an undergraduate physical chemistry class: A survey of student perception and attitudes, Journal of Applicable Chemistry, vol. 4, no. 6, pp. 1584-1591.

Mahayana IMH, Margunayasa IG, Wibawa IMC 2016, Pengaruh model pembelajaran POGIL dan minat belajar terhadap pemahaman konsep IPA siswa kelas IV, e-Journal PGSD Universitas Pendidikan Ganesha Jurusan PGSD, vol. 4, no. 1, pp. 1-11.

Malik, Adam 2010, 'Model pembelajaran inkuiri dengan menggunakan virtual laboratory dan real laboratory untuk meningkatkan penguasaan konsep dan keterampilan berpikir kritis siswa SMA pada topik listrik dinamis' Tesis, Universitas Pendidikan Indonesia, Bandung, Tidak diterbitkan. 
Moog, R \& Spencer, J 2008, "POGIL: An overview" in Process Oriented Guided Inquiry Learning (POGIL) edited by Moog, R \& Spencer, American Chemical Society, Washington DC, pp. 1-13.

Ningsih PE, Siswoyo, \& Astra IM 2015, Pengaruh metode POGIL (Process Oriented Guided Inquiry Learning) terhadap keterampilan proses sains peserta didik pada materi suhu dan kalor kelas $\mathrm{X}$ SMA, Prosiding Seminar Nasional Fisika (E-Journal) SNF 2015, vol. IV Oktober 2015, pp. 6772.

Ningsih, SM, Bambang S, \& Sopyan, A 2012, Implementasi model pembelajaran Process Oriented Guided Inquiry Learning (POGIL) untuk meningkatkan kemampuan berpikir kritis peserta didik. Unnes Physics Education Journal, vol. 1, no. 2, pp. 44-52.

Nur, M \& Wikandari, R 2000, Pengajaran Berpusat Kepada Siswa dan Pendekatan Kontruktivisme dalam Pengajaran. Surabaya, Universitas Surabaya, Pusat Studi Matematika dan IPA Sekolah.

Putra \& Sudarti 2015, Pengembangan sistem e-learning untuk meningkatkan keterampilan berpikir kritis mahasiswa Pendidikan Fisika, Jurnal Fisika Indonesia, vol 19, no 55, pp. 45-48.

Putri, NRT \& Sugiarto, B 2014, Implementasi Process Oriented Guided Inquiry Learning (POGIL) untuk melatih keterampilan metakognitif pada materi pokok reaksi reduksi-oksidasi. Unesa Journal of Chemical Education, vol. 3, no. 2, pp. 151-157.

Sartono, N, Rusdi, R \& Handayani, R 2017, Influence Of Learning Process Oriented Guided Inquiry Learning (POGIL) and Discovery Learning To Think Ability In Students Analysis Of SMAN 27 Jakarta In The Imun System Material, BIOSPHERE: Journal of Biology Education, vol. 10, no. 1, p. 60-67.

Tawil \& Liliasari 2013, Berpikir kompleks dan implementasinya dalam pembelajaran IPA, Badan Penerbit UNM, Makassar.

Widyaningsih SY, Haryono \& Saputro, S 2012, Model MFI dan POGIL ditinjau dari aktivitas belajar dan kreativitas peserta didik terhadap prestasi belajar, Jurnal Inkuiri, vol. 1, no. 3, pp. 266-275.

Zamista, AA \& Kaniawati, I 2015, Pengaruh Model Pembelajaran Process Oriented Guided Inquiry Learning Terhadap Keterampilan Proses Sains Dan Kemampuan Kognitif Siswa Pada Mata Pelajaran Fisika, EDUSAINS, vol. 7, no. 02, pp. 191-201.

Zawadzki, R 2010, Is Process Oriented Guided Inquiry Learning (POGIL) suitable as a teaching method in Thailand's higher education, Asian Jurnal on Education and Learning, vol. 1, no. 2, pp. 66-74. 